\title{
Accounting
}

\section{Taxpayer awareness, tac knowledge, tac sanctions, public service account ability and taxpayer compliance}

\author{
La Ode Anto ${ }^{a^{*}}$, Husin ${ }^{a}$, Wahyuniati Hamid ${ }^{a}$ and Nofian Lepong Bulan ${ }^{a}$
}

\begin{tabular}{l}
${ }^{a}$ Faculty of Economics and Business, \\
\hline C H R O N I C L E \\
\hline Article history: \\
Received: July 2, 2020 \\
Received in revised format: \\
September 302020 \\
Accepted: October 8,2020 \\
Available online: \\
October 12, 2020 \\
\hline Keywords: \\
Taxpayer compliance \\
Taxpayer awareness \\
Tax knowledge \\
Tax sanctions \\
Public service accountability
\end{tabular}

(C) 2021 by the authors; licensee Growing Science, Canada

\section{Introduction}

Taxes are mandatory contributions to the state owed by individuals or entities that are coercive based on law by not getting direct benefits and are used for the country's needs for the greatest prosperity of the people. The role of tax as domestic revenue is very dominant, but it is still not optimal when seen from the number of taxpayers who have not become compliant taxpayers. Taxpayer compliance is a condition where taxpayers fulfill all tax obligations and carry out their tax rights (Devano \& Rahayu, $2006,10)$. Awareness of taxpayers is very difficult to realize. Until now, the people paying taxes have not reached the level expected, and tax awareness is still lacking in the community. Lack of awareness and compliance of taxpayers in Indonesia is triggered by various things such as lack of understanding of taxation and the assumption that paying taxes is a loss because it reduces income, and there is an assumption that the allocation of tax use is not transparent and there are cases of tax fraud (Listyowati et al., 2018). Oladipupo and Obazee (2016) suggest that in many developing countries, tax administration is usually weak, and is characterized by embezzlement, corruption, and coercion. In many cases, the level of overall tax compliance is still low. However, there are still efforts that can be made so that people are fully aware of paying taxes. When people have awareness, paying taxes will be done voluntarily rather than forced. To improve taxpayer compliance, policy makers in this case, the government need a combination of persuasive methods to change people's behavior (Marandu et al., 2015).

* Corresponding author

E-mail address: laodeanto@gmail.com (L.O. Anto) 
James and Aley (2004) suggest that it is not easy to persuade all taxpayers to fulfill all tax system requirements. Tax compliance tends to be a more significant aspect of tax policy. This is due to most of the old problems that still exist and new considerations that are developing such as self-assessment, the emergence of the global economy, and electronic commerce. Furthermore, people are reluctant to pay taxes because of intellectual and moral development of the community, taxation systems that are difficult for the public to understand, and control systems cannot be implemented properly. Tax knowledge is information possessed by taxpayers regarding matters relating to taxation. Knowing how to recapitulate gross income each month, pay income tax, and report taxes are activities that can measure how much tax knowledge is possessed by taxpayers. If taxpayers do not have taxation information, it will affect taxpayer compliance (Mardiasmo, 2016).

Taxpayer compliance can be influenced by various factors including the existence of government policies and programs, awareness of taxpayers in paying taxes, knowledge and understanding of tax regulations, tax sanctions, and tax services (Listyowati, et al., 2018). Furthermore, taxpayer compliance can also be influenced by tax administration systems, information and accounting systems, tax law enforcement systems, tax audits, and tax rates, education levels, income levels, and perceptions of taxpayers towards tax sanctions. If all of these factors can be improved and applied in the taxation system, it is not impossible that tax compliance can be realized (Oladipupo \& Obazee, 2016). Several studies on tax compliance have been carried out with inconsistent and contradictory results. Research conducted by Arvian and Djeni (2018), Nurkhin, et al. (2018), and Siat and Toly (2013) found that taxpayer awareness had a positive effect on taxpayer compliance in paying taxes, but the results of this study contradicted the findings of Famami and Norsain (2019) and Nurgroho and Raharjo (2016). They indicated that awareness of taxpayers had no significant effect on taxpayer compliance. Furthermore, the results of Nurkhin, et al. (2018), Arvian and Djeni (2018), and Hardiningsih and Yulianawati (2011) indicated that tax knowledge has a positive effect on taxpayer compliance, while Andinata (2015) found that knowledge of tax regulations does not affect tax compliance. The results of Arvian and Djeni's research (2018), Gunarso (2016), Kamil (2015), and Ngadiman and Huslin (2015) found that tax sanctions had a significant effect on taxpayer compliance in paying taxes, which was not in line with the findings of Rahmawati and Yulianto (2018), Famami and Norsain (2018), and Oladipupo and Obazee (2016) since they reported that tax penalties do not affect taxpayer compliance. Likewise, the research findings of Arvian and Djeni (2018) and Febriani and Kusmurianto (2015) indicated that public service accountability has a positive and significant effect on tax compliance, and the results is not in line with the research findings of Famami and Norsain (2018) and Rahmawati and Yulianto (2018) that the public services has no significant effect on tax compliance in paying taxes.

Based on the above research gap, this study tries to fill the gap of previous research. This study is also a development of research conducted by several previous researchers who examined the factors that affect taxpayer compliance, suggesting to further analyze tax enforcement in accordance with applicable taxation rules and improving the quality of services so that taxpayers are more compliant in paying tax obligations.

\section{Literature review}

\subsection{Theory of Planned Behavior}

Theory of planned behavior (TPB) is the development of the theory of reasoned action (TRA) by adding a construct that is perceived behavioral control. This construct was added in the TPB to control individual behavior that is limited by its shortcomings and limitations from the lack of resources used to conduct their behavior (Jogiyanto, 2007:61). The emergence of an intention to behave is determined by three factors, namely: 1). Behavioral beliefs are individual beliefs about the results of a behavior and evaluation of these results. 2). Normative beliefs are beliefs about the normative expectations of others and motivation to meet those expectations. 3). Control beliefs are beliefs about the existence of things that support or hinder the behavior that will be displayed and the perception of how strong the things that support and inhibit the behavior (perceived power). Theory of Planned of Behavior is relevant to explain the behavior of taxpayers in fulfilling their tax obligations. Behavioral beliefs, normative beliefs, and control beliefs as three factors that determine a person to behave. After there are three factors, then someone will enter the intention stage, then the last stage is behavior. The intention stage is the stage where someone has the intention or intention to behave, while the behavior is the stage someone behaves. Awareness of taxpayers, tax authorities, and tax sanctions can be factors that determine the formal tax compliance behavior. After the taxpayer has the awareness to pay taxes, motivated by tax authorities and tax sanctions, the taxpayer will have the intention to pay taxes and then realize those intentions. Usually someone believes in the results that will be obtained before deciding to act or not (Manuputty \& Sirait, 2016).

\subsection{Attribution Theory}

Attribution theory explains that when individuals observe the behavior of other individuals, the individual tries to explain whether the behavior is caused by internal or external parties (Robbins \& Judge, 2008). Attribution theory assumes that people 
try to determine why people do what they do, that is attributes cause behavior. Someone trying to understand why someone else is doing something that might be one or more of the attributes that cause that behavior. Three stages underlie an attribution, namely: 1). People must see or observe behavior. 2). Then one must believe that the behavior was intentionally carried out. 3 ). Then people must determine whether they believe that other people are forced to carry out behavior or not. Attribution theory is very relevant to explain the internal and external conditions of taxpayers in fulfilling their tax obligations. Taxpayer compliance can be related to the attitude of taxpayers in making an assessment of the tax itself. Someone's perception or thought to make judgments about other individuals is influenced by internal and external factors of other individuals (Jatmiko, 2006).

\subsection{Social Learning Theory}

The concept of this theory emphasizes the cognitive component of the mind, understanding and evaluation. Bandura (1986) says that the process of social learning includes: 1). Attentional process, that is, people will only learn from someone or a model, if they already know and pay attention to that person or model. 2). The process of retention is the process of remembering the actions of a model after the model is no longer easily available. 3). The process of motor reproduction is the process of turning observation into action. 4). The process of reinforcement is a process in which individuals are provided with positive stimulation or appreciation in order to behave in accordance with the model. This social learning theory is relevant to explain the behavior of taxpayers in fulfilling their tax obligations. Someone will be obedient to pay taxes on time, if through observation and direct experience that the tax collection has made a real contribution to the development in the region. Someone will also be obedient to pay taxes if he has paid attention to tax services, as well as the tax service system. Related to the strengthening process, the process is quite relevant if it is related to the effect of tax sanctions on taxpayer compliance (Jatmiko, 2006).

\subsection{Taxpayer Compliance}

Tax compliance is an obligation that is fulfilled by taxpayers based on the taxpayers' perception of the fairness of the tax burden they bear, and the effect of satisfaction on government services. Tax compliance can be defined as a condition where taxpayers fulfill all tax obligations. Taxpayers are said to be obedient if the taxpayer does not have arrears or delay in paying taxes (Nurmantu, 2010). Obedient means that the taxpayer has a willingness to fulfill his taxation obligations in accordance with applicable regulations without the need for inspection, careful investigation, warning or threat and the application of legal and administrative sanctions (Gunadi, 2013: 94). There are two types of compliance, namely: 1) formal compliance i.e. a condition where taxpayers formally fulfill obligations in accordance with provisions in tax laws, 2) material compliance, namely a condition where taxpayers substantively or substantially fulfill all tax material provisions, namely according to the content and spirit of taxation laws and managerial compliance which also includes formal compliance (Rahayu, 2010).

\subsection{Taxpayer Awareness}

Taxpayer awareness is the attitude of understanding corporate or individual taxpayers to understand the meaning, function and purpose of tax payments. Awareness of taxpayers is the most important factor in the modern taxation system (Harahap, 2004: 43). Consciousness is an element in humans to understand reality and how they act or behave towards reality. Jatmiko (2006) explains that consciousness is a state of knowing or understanding. Awareness of paying taxes that encourage taxpayers to pay taxes, namely: 1). Awareness that tax is a form of participation in supporting the country's development. 2). Awareness that delaying tax payments and reducing the tax burden is very detrimental to the country. 3). Awareness that taxes are determined by law and can be forced. Low public tax awareness is often one of the causes of the large tax potential that cannot be captured. Tax awareness is often an obstacle in the issue of collecting taxes from the public. It has also been empirically proven that the higher taxpayer tax awareness is, the higher the level of taxpayer compliance (Nurkhin, et al., 2018). Mangkoesoebroto (2010:52) states that awareness of taxpayers is often associated with willingness and compliance in carrying out taxation rights and obligations in accordance with applicable regulations, especially in the following matters: 1). Increasingly higher public knowledge is easy for the government to raise awareness of taxpayers especially regarding the relationship between costs and benefits of every government activity. 2). Level of education, this is needed in understanding taxes and filling out tax forms that sometimes feel complicated for the community. 3). The prevailing system is mainly a fair tax system and an easy and simple administration system. Awareness of the taxpayer is a good faith someone to fulfill the obligation to pay taxes based on a sincere conscience. Awareness of taxpayers can be seen from their sincerity to fulfill their tax obligations (Dharma \& Suardana, 2014).

\subsection{Tax Knowledge}

Someone who has education will be aware and obedient to their rights and obligations, without having to be forced and threatened by some sanctions and penalties. Low tax knowledge can lead to mistrust and negative attitudes towards taxes, while good tax knowledge is correlated with a positive attitude towards taxes. Taxpayer knowledge of a taxpayer can be measured through knowledge and understanding of the rights, obligations and responsibilities as a taxpayer. If taxpayers already know 
and understand their obligations as taxpayers, they will carry out these obligations to obtain rights and carry out responsibilities as taxpayers. Understanding tax regulations is the process by which taxpayers know taxation and apply that knowledge to tax payments. To improve taxpayer compliance, taxpayers must understand their rights and obligations as taxpayers (Suryadi, 2006). Indicators of tax knowledge consist of knowledge of tax regulations, knowledge of calculating the amount of tax payable, and knowledge of filling out notification letters. There are 2 factors that influence tax knowledge, namely: 1) internal factors, including education, interests, experience, and age, 2) external factors such as economy, information, and culture/environment (Notoatmodjo, 2003: 37). Knowledge of taxpayers about tax payments and methods will greatly help make it easier to meet their tax obligations. High or low knowledge of taxpayers can be measured by understanding the procedure or how to fill out notification letters, understanding the reporting deadline, and understanding tax and administrative sanctions (Taslim, 2007).

\subsection{Tax Sanctions}

Sanction is an action in the form of punishment given to people who break the rules. Rules or laws are signs for someone to do something about what should be done and what should not be done. Sanctions are needed so that regulations or laws are not violated. Tax sanctions are guarantees that the provisions of tax legislation (tax norms) will be obeyed/complied with, in other words taxation sanctions are a means of preventing taxpayers from violating tax norms (Mardiasmo, 2016). There are two types of taxation sanctions, namely administrative sanctions consisting of fines, interest and increases, and criminal sanctions consisting of criminal fines, and imprisonment. Indicators of taxation sanctions are criminal sanctions, administrative sanctions, heavy sanctions, tax sanctions imposed on offenders without tolerance, tax penalties for tax violations can be negotiated. With tax sanctions, it is expected that taxpayers can carry out their obligations properly. So that with tax sanctions there is hope that will increase compliance in paying taxes by taxpayers (Listyowati, et al., 2018)

\subsection{Public Service Accountability}

In the context of public services, accountability is a measure that shows how high the level of conformity of service delivery is with the size of external values or norms that exist in society or that are owned by stakeholders. Thus, the benchmark in the accountability of public services is the public itself, which is the meaning of values or norms that are recognized, applicable and developed in public life. These values or norms include service transparency, principles of justice, guarantees of law enforcement, human rights, service orientation developed towards service user communities. So that values or norms can continue to be implemented it requires a control from the community (Dwiyanto, 2002: 10). Widodo (2001) explains accountability as a concept relating to external standards that determine the truth of a bureaucratic action. External control becomes a source of accountability that motivates and encourages officials to work hard. The wider community as an objective assessor will determine whether or not a bureaucracy is accountable. Accountability of public services is assessed from the performance of the apparatus services towards taxpayers.

The service is simple, open, smooth, precise, complete, reasonable, and affordable by the customer and must meet the elements of rights and obligations, according to the conditions of need, can provide security, comfort, smoothness and legal certainty that can be accounted for, and cooperation partnership. There are five dimensions that need to be considered when others assess services, namely: 1) tangible, including physical facilities (buildings), equipment, employees, and communication targets, 2) empathy, including ease of contact, good communication, attention personal, and understand customer needs,3) responsiveness, 4) reliability, namely the ability to provide the promised service immediately, accurately, reliably, and satisfactorily, 5) assurance, covers ability, knowledge, courtesy, as well as the trustworthiness of the staff (Kotler, 2005). Based on the theoretical basis that has been stated previously, the conceptual framework is stated as given in Fig. 1.

\subsection{Research Hypothesis}

Awareness of taxpayers means that taxpayers are willing to carry out their tax obligations such as registering, calculating, paying and reporting the amount of tax payable. Nurkhin, et al. (2018) states that taxpayer awareness has a real influence on taxpayer compliance and non-compliance. Taxpayers with high awareness tend to be more obedient in paying taxes compared to taxpayers with low awareness. Awareness of the taxpayer is a good faith someone to fulfill the obligation to pay taxes based on a sincere conscience. People who have tax awareness mean that taxpayers are obedient to pay taxes because they do not feel disadvantaged from the tax collection carried out and feel no coercion (Arum and Zulaikha, 2012). Research conducted by Aviana and Djeni (2018), Nurkhin, et al. (2018) and Siat and Toly (2013) state that taxpayer awareness has a positive and significant effect on taxpayer compliance in paying taxes. Likewise with the results of research by Palil, Rusyidi, and Ahmad (2013) and Adinata (2015), Ilhamsyah, et al. (2016) found that taxpayer awareness of tax obligations has a positive effect on compliance of individual taxpayers in paying taxes. The results of the study are also supported by Fajrian, Endang, and Prasetya (2015), Agustiningsih and Isroh (2016), and Savitri and Musfialdi (2016) that awareness of taxpayers has a positive and significant effect on tax compliance. In contrast to the results of research conducted by Famami and Norsain (2019) and 
Nugroho, Andini, and Raharjo (2016) which concluded that taxpayer awareness partially does not affect taxpayer compliance in paying tax obligations.

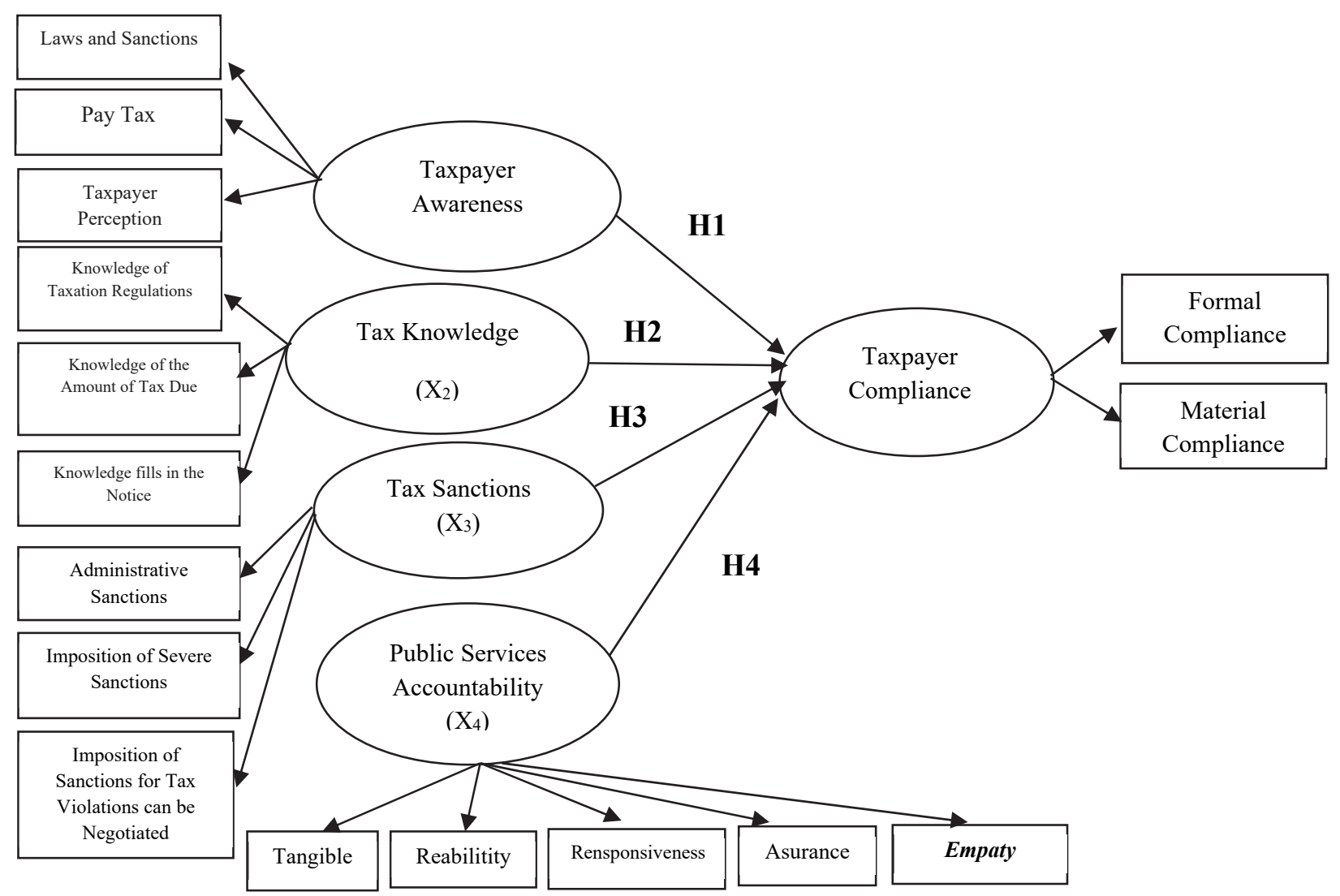

Fig. 1. Conceptual Framework

$\mathbf{H}_{1}$ : Awareness of taxpayers has a positive and significant effect on taxpayer compliance.

One of the factors that influence taxpayer compliance is knowledge of taxation information obtained by taxpayers. Knowledge of taxation is the ability of a taxpayer to know tax regulations both about the tax rate based on the law to be paid, as well as tax benefits that will be useful for their lives. Taxpayers who do not have the perception of taxation tend to have disobedient attitudes and vice versa if they understand about taxation, they will be compliant and will be more maximized in settling their tax obligations (Famami \& Norsain, 2019). Taxpayers will try to fulfill their obligations to avoid sanctions in force in tax regulations (Rahayu, 2017). The aspect of tax knowledge for taxpayers greatly influences the attitude of taxpayers towards fair taxation systems. The better quality of knowledge will provide an attitude of fulfilling obligations properly through the existence of a country's taxation system which is considered fair. With the increase in public taxation knowledge through taxation education both formal and non-formal it will have a positive impact on taxpayer compliance in paying taxes (Sari \& Fidiana, 2017). The results of research by Nurkhin, et al. (2018), Rahayu (2017), Olaoye, et al. (2017), Oladipupo and Obazee (2016), Redae and Sekhon (2016), and Ilhamsyah, et al. (2016), found that tax knowledge has a positive and significant effect on tax compliance. But there are other findings from the results of Andinata (2015) that tax knowledge has no significant effect on taxpayer compliance in fulfilling tax obligations.

$\mathbf{H}_{2}$ : Tax knowledge has a positive and significant effect on taxpayer compliance.

Tax sanctions if related to the theory of legitimacy cannot be separated from taxation laws and implementing regulations. Taxpayers must still carry out their obligations in a timely manner even if compliance is not given an award. Taxpayers who deliberately do not fulfill their tax obligations will be penalized. Tax sanctions are guarantees that the provisions of tax legislation (tax norms) will be obeyed (Mardiasmo, 2016: 60). Sanctions become a guarantee that taxpayers will not neglect to carry out their obligations as taxpayers, with sanctions that provide a deterrent effect, taxpayer compliance will increase. The research results of Gunarso (2016), Ngadiman and Huslin (2015) and Kamil (2015) stated that tax sanctions had a positive effect on taxpayer compliance. This is supported by the results of Arviana and Djeni (2018) which found that tax sanctions had a 
positive and significant effect on tax compliance in paying taxes. In contrast to the results of research by Famami and Norsain (2019) and Rahmawati and Yulianto (2018) which concluded that taxation sanctions had no significant effect on the level of tax compliance.

H3: Tax sanctions have a positive and significant effect on taxpayer compliance.

In accordance with statutory provisions, the implementation of public services must be accountable, both to the public and to the superiors/ leaders of the service units of government agencies. Accountability of public services is related to the ability of officials to serve taxpayers to fulfill all their needs in a transparent and open manner. Quality of service can be measured by the ability to provide satisfactory services; can provide services with responses, abilities, politeness, and trustworthy attitudes possessed by the tax authorities. Tax services are acts of tax officials when providing services (Gautama, 2014). Tax officials should be honest, responsible, understanding, objective, polite (not arrogant), and avoiding despicable acts (Siat \& Toly, 2013). As good as the services provided by tax officers to taxpayers, will encourage taxpayers to carry out their tax obligations so that tax compliance can be created (Sari and Fidiana, 2017). The results of Arviana and Djeni (2018), Awaluddin and Tamburaka (2017), and Febriani and Kusmurianto (2015) show that public service accountability has a positive and significant effect on taxpayer compliance. The better the accountability of public services, the higher the tax compliance. This is not in line with the results of research by Famami and Norsain (2019) and Rahmawati and Yulianto (2018) which concludes that service quality has no significant effect on tax compliance.

H4: Accountability of public services has a positive and significant effect on taxpayer compliance.

\section{Research method}

This type of research is basic research which is a research method used to develop theories and does not pay attention to the practical uses which are directly practical Sugiyono (2013:4). This research was conducted in Kendari City with the object of research is motor vehicle taxpayer compliance and the variables that influence it are taxpayer awareness, tax knowledge, tax sanctions, and public service accountability. The population in this study were all motor vehicle taxpayers in Kendari City, amounting to 115.240 taxpayers. The sampling used in this study is non probability sampling. Non probability sampling is that every element in the population does not have the same opportunity to be chosen as a sample, even the probability of certain members to be chosen is unknown. The sampling technique in this study was carried out using accidental sampling technique where the determination of sample members taken based on not planned in advance but obtained or encountered suddenly. Determination of the sample can be done using the Slovin formula and obtained a sample size of 90 taxpayers. The type of data used is primary data obtained through a questionnaire using a Likert scale. The data analysis technique is multiple linear regression statistical analysis using IBM SPSS Version 21 Software.

\section{Results}

\subsection{Taxpayers Awareness}

Descriptive items of statements relating to taxpayer awareness indicate that the average score of taxpayer awareness variables of 4.16 is included in the excellent category. This shows that taxpayer awareness is in a very good valuation condition when observed from the indicators of laws and sanctions in tax regulations, awareness that paying taxes is an obligation, and perceptions of taxpayers regarding the implementation of tax penalties.

\subsection{Tax Knowledge}

Descriptive items of statements related to tax knowledge by taxpayers indicate that the average score of tax knowledge variables of 4.19 is included in the excellent category. This means that tax knowledge by taxpayers is in a very good valuation condition when observed from the dimensions of tax regulations, the amount of tax owed, and in filling out the tax submission letter.

\subsection{Tax Sanctions}

Descriptive items of statements relating to tax sanctions indicate that the average score of the variable taxpayer sanctions of 4.06 is included in the excellent category. This means that the taxpayer's sanctions that are applied are in a very good assessment condition when observed from the dimensions of administrative sanctions, fairly severe sanctions, and sanctions for violations that can be negotiated. 
Descriptive items of statements relating to public service accountability indicate that the average score of public service accountability variables of 4.20 is included in the excellent category. This means that the accountability of public services is in a very good evaluation condition when observed from indicators of physical evidence, reliability, responsiveness, guarantees and empathy of the public during the tax payment process.

\subsection{Taxpayer Compliance}

Descriptive items of statements relating to taxpayer compliance indicate that the average score of taxpayer compliance variables of 4.15 is included in the excellent category. This means that taxpayer compliance is in a good assessment condition when observed from the dimensions of formal compliance and material compliance by officers in providing services to the public in the process of tax payments.

\subsection{Hypothesis Test}

The results of multiple linear regression analysis are as shown in the following table.

Table 1

$\underline{\text { Results of Multiple Linear Regression Analysis }}$

\begin{tabular}{|c|c|c|c|c|c|c|}
\hline & \multirow{2}{*}{ Model } & \multicolumn{2}{|c|}{ Unstandardized Coefficients } & \multicolumn{3}{|c|}{ Standardized Coefficients } \\
\hline & & B & Std. Error & Beta & $\mathbf{t}$ & Sig. \\
\hline \multirow[t]{5}{*}{1} & (Constant) & 14.212 & 3.349 & & 4.244 & .000 \\
\hline & Taxpayers Awareness (X1) & .601 & .360 & .486 & 4.824 & .000 \\
\hline & Tax Knowledge (X2) & .427 & .288 & .366 & 2.669 & .009 \\
\hline & Tax Sanctions (X3) & .325 & .334 & .339 & 2.356 & .032 \\
\hline & Public Service Accountability(X4) & .310 & .372 & .281 & 2.074 & .040 \\
\hline
\end{tabular}

Based on the analysis results obtained by the multiple linear regression equation as follows:

$$
\mathrm{Y}=0.486 \mathrm{X}_{1}+0.366 \mathrm{X}_{2}+0.339 \mathrm{X}_{3}+0.281 \mathrm{X}_{4},
$$

the multiple linear regression equation models can be interpreted as follows: 1). Value of the taxpayer awareness regression coefficient $\left(\mathrm{X}_{1}\right)$ is equal to 0.486 . This shows that there is a positive effect where the awareness of taxpayers is increased, the compliance of taxpayers $(\mathrm{Y})$ will also become better. 2). Value of the tax knowledge regression coefficient $\left(\mathrm{X}_{2}\right)$ is equal to 0.366. This shows that there is a positive effect and if the tax knowledge increases then the taxpayer compliance $(\mathrm{Y})$ will get better. 3). Regression coefficient value of tax sanctions $\left(\mathrm{X}_{3}\right)$ is also equal to 0.339 . This shows that there is a positive effect and if the variable of tax sanctions increases, the compliance of taxpayers (Y) will be better and 4). The value of the public service accountability $\left(\mathrm{X}_{4}\right)$ regression coefficient is 0.281 . This shows that there is a positive effect and if the variable accountability of public services has increased the compliance of taxpayers $(\mathrm{Y})$ will be better. The multiple correlation coefficient for taxpayer awareness variables $\left(\mathrm{X}_{1}\right)$, tax knowledge $\left(\mathrm{X}_{2}\right)$, tax sanctions $\left(\mathrm{X}_{3}\right)$, public service accountability $\left(\mathrm{X}_{4}\right)$ and taxpayer compliance (Y) yields $\mathrm{R}=0.852$. Thus, all four variables simultaneously have strong relationships with taxpayer compliance. The coefficient of determination $\mathrm{R}$ square is equal to 0.726 or $72.6 \%$. This shows that the contribution of variables that affect taxpayer compliance by $72.60 \%$, while the rest $(27.40 \%)$ is influenced by other variables not included in this analysis. Test results show that: a). The taxpayer awareness variable $\left(\mathrm{X}_{1}\right)$ partially has a positive and significant effect on taxpayer compliance. This is indicated by the results of the $t$-test at the significance level. $0,000<\alpha=0.05$. Thus, $\mathrm{H}_{1}$ is accepted. $\mathrm{b}$ ). The tax knowledge variable $\left(\mathrm{X}_{2}\right)$ partially has a positive and significant effect on taxpayer compliance. This is indicated by the results of the $t$-test at the significance level. $0.009<\alpha=0.05$. Thus, $\mathrm{H}_{2}$ is received. c). The tax sanction variable $\left(\mathrm{X}_{3}\right)$ partially has a positive and significant effect on taxpayer compliance. This is indicated by the results of the $t$ test at the significance level. $0.032<\alpha=0.05$. Thus, $\mathrm{H}_{3}$ is accepted. d). The tax service accountability variable $\left(\mathrm{X}_{4}\right)$ partially has a positive and significant effect on taxpayer compliance. This is indicated by the results of the $t$ test at the significance level. $0.040<\alpha=0.05$. Thus, $\mathrm{H}_{4}$ is accepted.

\section{Discussion}

\subsection{Effect of Taxpayer Awareness on Taxpayer Compliance}

The results of this study found that taxpayer awareness had a significant positive effect on taxpayer compliance. Awareness of taxpayers has logical consequences for taxpayers, namely the willingness of taxpayers to contribute funds to the implementation of the tax function by paying taxes on time and in the right amount. Taxpayers who have high awareness do not consider paying taxes a burden, but they consider this an obligation and their responsibility as citizens so that they do not object and pay their 
taxes voluntarily. Awareness of the taxpayer is a good faith someone to fulfill the obligation to pay taxes based on a sincere conscience. Awareness of taxpayers can be seen from their sincerity to fulfill their tax obligations (Dharma \& Suardana, 2014). It is realized by taxpayers that tax as the biggest contributor to state revenue, has a very big influence on the sustainability of a country's development even though there are other sectors that also contribute to a country's revenue. There are two main functions of the tax, namely the budget function and the regulating function. For the government the tax in the budget aspect is used to finance government needs, and in the regulated aspect is as a tool to control and carry out government policies in the social and economic fields (Mardiasmo, 2016). The results of this study reinforce the findings of previous research studies conducted by Aviana and Djeni (2018), Nurkhin, et al. (2018), Ilhamsyah, et al. (2016), Adinata (2015), Siat and Toly (2013), and Palil, Rusyidi, and Ahmad (2013) who stated that taxpayer awareness had a positive and significant effect on taxpayer compliance in paying taxes.

\subsection{Effects of Tax Knowledge on Taxpayer Compliance}

The results of this study found that taxpayer knowledge had a significant positive effect on taxpayer compliance. Tax knowledge is information that can be used by taxpayers as a basis for acting, making decisions, and for taking certain directions or strategies with respect to the implementation of their rights and obligations in the field of taxation. If taxpayers do not have taxation information, it will affect taxpayer compliance (Mardiasmo, 2016). Meanwhile, knowledge can be classified into three, namely procedural knowledge, declarative knowledge, and tecit knowledge. Procedural knowledge puts more emphasis on how to do things. Declarative knowledge answers the question whether something is false or true, while tecit knowledge is knowledge that cannot be expressed in language. High or low knowledge of taxpayers can be measured by understanding the procedure or how to fill out notification letters, understanding the reporting deadline, and understanding tax and administrative sanctions (Taslim, 2007). Furthermore, one's attitude and mindset or understanding of taxes will affect his attitude in fulfilling tax obligations. Factors of taxpayer knowledge influenced by the level of knowledge of taxpayers can be measured by (a) understanding the procedures or ways to fill out notification letters, (b) understanding the reporting deadline, and (c) understanding tax and administrative sanctions. On the other hand, that there is a taxpayer relationship with the government, namely their trust in the government is an important consideration in complying with tax regulations and influencing them in paying tax compliance. The results of this study support the results of previous studies conducted by Nurkhin, et al. (2018), Rahayu (2017), Olaoye, et al. (2017), Oladipupo and Obazee (2016), Redae and Sekhon (2016), and Ilhamsyah, et al. (2016) which concluded that tax knowledge has a positive and significant effect on taxpayer compliance.

\subsection{Effects of Tax Sanctions on Taxpayer Compliance}

The results of this study indicate that tax sanctions have a significant positive effect on taxpayer compliance in paying taxes. The main purpose of giving witnesses is not to increase state revenue but to increase public awareness of fulfilling their tax obligations. The law has set general provisions and procedures for taxation regulations, including tax penalties. Tax sanctions are guarantees that the provisions of tax legislation (tax norms) will be obeyed/ complied with, in other words taxation sanctions are a means of preventing taxpayers from violating tax norms (Mardiasmo, 2016). There must be tax penalties for taxpayers so that taxpayers comply with tax regulations. Taxpayers are of the opinion that if the taxation sanctions will do more harm then the taxpayer will fulfill his obligations (Jatmiko, 2006). The results of this study are in line with the results of previous studies conducted by Arviana and Djeni (2018), Gunarso (2016), Ngadiman and Huslin (2015), Kamil (2015), Arum and Zulaikha (2012), and Muliari and Setiawan (2011) who stated that tax sanctions has a positive and significant effect on taxpayer compliance.

\subsection{Effect of Public Service Accountability on Taxpayer Compliance}

The results of this study indicate that public service accountability has a significant positive effect on taxpayer compliance in paying taxes. To achieve accountability for taxpayer service recipients, quality of service is demanded which is reflected in transparency, accountability, conditionality, participatory, equality of rights, and balance of rights and obligations. In essence, the quality of public services can be known by comparing the taxpayers' perceptions of the services they actually want. If the service in practice received by the taxpayers is the same as their hopes or desires, then the taxpayer is said to be satisfactory or of good quality. Thus, the benchmark in the accountability of public services is the public itself, which is the meaning of values or norms that are recognized, applicable and developed in public life. These values or norms include service transparency, principles of justice, guarantees of law enforcement, human rights, service orientation developed towards service user communities. So that values or norms can continue to be implemented it requires a control from the community (Dwiyanto, 2002: 10). One effort that can be done to facilitate taxpayers in meeting their tax obligations is to reform tax administration. The rapid development of the use of information technology and the web was followed by governments who also used this technology to provide services with the aim of improving service quality and achieving efficiency in their operations. Technological advances that continue to develop make the government innovate to provide better service quality so as to 
increase compliance and satisfaction of taxpayers in paying taxes. The results of this study support the results of previous studies conducted by Arviana and Djeni (2018), Awaluddin and Tamburaka (2017), Febriani and Kusmurianto (2015), Gautama, 2014), and Siat and Toly (2013), which concluded that public service accountability has a positive and significant effect on taxpayer compliance.

\section{Conclusions}

Based on the problems, objectives, results of the analysis and discussion in this study, several conclusions can be drawn as follows: 1). Awareness of taxpayers has a positive and significant effect on taxpayer compliance, meaning that the higher the awareness of taxpayers, the more obedient there will be in paying their tax obligations. 2). Tax knowledge has a positive and significant effect on tax compliance, meaning that the higher the tax knowledge of taxpayers, the more obedient they will be in paying their tax obligations. 3). Tax sanctions have positive and significant effects on tax compliance, meaning that the higher the tax sanctions, the more it will encourage taxpayers to comply in paying their tax obligations. 4). Public services accountability has a positive and significant effect on tax compliance, meaning that the higher the public services accountability, the more it will encourage taxpayers to comply in paying their tax obligations. Based on the results of the discussion concluded in this study, the author's recommendations are as follows: 1). The government should always improve the quality of service in the tax payment process so that it encourages taxpayers to pay their tax obligations in a timely manner. 2). Future research is expected to broaden the study of taxpayer compliance by expanding tax objects and adding other relevant variables such as tax rates and income levels of taxpayers.

\section{References}

Agustiningsih, W., \& Isroh. (2016). The effect of e-filling application, taxation understanding level, and taxpayer awareness on taxpayer compliance in KPP Pratama Yogyakarta. Nominal Journal, 2, 107-122.

Andinata, M.C. (2015). Analysis of factors affecting the compliance of individual taxpayers in paying taxes: Case study at the Surabaya RungkutPratama tax service office in Surabaya. Calyptra:University of Surabaya Student Scientific Journal, 4(2), $1-15$.

Arum, H.P., \& Zulaikha. (2012). The influence of taxpayer awareness, fiscus services, and tax sanctions on the compliance of individual taxpayers conducting business activities and free work (Study in the Cilacap KPP Area). Diponegoro Journal of Accounting, 1(1), 1-8.

Arviana, N., \& Djeni, I.W. (2018). Factors affecting the compliance of individual taxpayers. Muara Journal of Economics and Business, 2(1), 146-154.

Awaluddin, I., \& Tamburaka, S. (2017). The effect of services quality and taxpayer satisfaction on compliance payment tax motor vehicles at office one roof system in Kendari. The International Journal of Engineering and Science, 6(11), 25-34.

Bandura, A. (1986). Social Foundations of Thought and Action. Englewood Cliffs, NJ: Prentice Hall.

Devano, S., \& Rahayu, S. K. (2006). Taxation: Concepts, Theories and Issues. Jakarta: Kencana Prenada Media Group.

Dharma, G.P.E., \& Suardana. (2014). The influence of taxpayer awareness, tax socialization, and service quality on taxpayer compliance in paying PKB and BBNKB. E-Journal of Accounting, Udayana University, 8(2), 340-353.

Dwiyanto, A. (2002). Indonesian Bureaucratic Reform. Yogyakarta: Center for Population and Policy Studies.

Fajrian, N.A., Endang, N.P., \& Prasetya, A. (2015). The influence of perception of the implementation of the national tax census, The attitudes of taxpayers on the implementation of penalty sanctions and tax awareness on taxpayer compliance: Study on individual taxpayers in Mojokerto City). Journal of Taxation, 1(1).

Famami, A.H., \& Norsain. (2019). Factors influencing taxpayers in KPP PratamaPamengkasan. Journal of the Academy of Accounting, 2(2), 104-118.

Febriani, Y., \& Kusmurianto. (2015). Analysis of factors affecting taxpayer compliance. Accounting Analysis Journal, 4(4), 113.

Gautama, M. (2014). Analysis of factors affecting individual tax compliance in paying taxes. Journal of Science and Accounting Research, 3(12), 72-86.

Gunadi (2013). Comprehensive Guide to Income Tax. Jakarta: Bee Media Indonesia.

Gunarso, P. (2016). Tax examination and tax sanctions on the compliance of corporate taxpayers at KPP Kepanjen Malang Regency. Journal of Finance and Banking, 20(2), 214-223.

Harahap, A. A. (2004). New Indonesian Tax Paradigm. Economic perspective.

Hardiningsih, P., \& Yulianawati, N. (2011). Factors that affect tax willpower. Financial and Banking Dynamics, 3(1), 126-143.

Ilhamsyah, Endang, M. G. W., \& Dewantara, R. Y. (2016). The influence of taxpayer understanding and knowledge of tax regulations, taxpayer awareness, service quality, and tax sanctions on motor vehicle taxpayers compliance (Study of Malang City Samsat). Journal of Taxation (JEJAK), 8(1), 1-9

James, S., \& Alley, C. (2004). Tax compliance, self-Assessment and Tax Administration. Journal of Finance and Management in Public Services, 2(2), 27-42. 
Jatmiko, A.N. (2006). Effect of Taxpayer Attitudes on the Implementation of Taxpayer Compliance. Thesis. Semarang: Postgraduate Masters Degree in Accounting in Diponegoro University.

Jogiyanto, H. (2007). Portfolio Theory and Investment Analysis, Issue 5, Yogyakarta: BPFE.

Kamil, N.I. (2015). The effect of taxpayer awareness, knowledge, tax penalties and tax authorities services on the tax compliance (Survey on the Individual Taxpayer at Jabodetabek \& Bandung). Research Journal of Finance and Accounting, 6(2), 169222.

Kotler, P. (2005). Marketing Management, Volume I, Jakarta: PT. Index.

Listyowati, Samrotun, Y., \& Suhendro. (2018). Factors affecting taxpayer compliance in paying taxes. Airlangga Accounting and Business Research Journal, 3(1), 372-395.

Mangkoesoebroto, G. (2010). Public Economy. Third Edition. Yogyakarta: BPFE.

Manuputty, I.G., \& Sirait, S. (2016). Effects of taxation knowledge and self assessment system implementation on taxpayer awareness and its impact on taxpayer compliance in Jakarta Panjaringan tax office. Media Accounting Taxation, 1(2), 4458.

Marandu, E. E., Mbekomize, C. J. and Ivezue, A. N. (2015). Determinants of Tax Compliance: A Review of Factors and Conceptualizations. International Journal of Economics and Finance, 1(9), 207-218.

Mardiasmo. (2016). Taxation. Latest edition. Yogyakarta: Andi.

Muliari, N. K., \& Setiawan, P. E. (2011). Influence of perception on tax sanctions and taxpayer awareness on the compliance of personal taxpayer reporting at the East Denpasar Pratama tax service office. Scientific Journal of Business Accounting, $6(1), 16-27$.

Ngadiman \& Huslin, D. (2015). The effects of sunset policy, tax amnesty, and tax sanctions on taxpayer compliance (Empirical Study at the Jakarta Kembangan Pratama Tax Service Office). Journal of Accounting, 19(2), 225-241.

Notoatmodjo, S. (2003). Health Education and Behavior. Jakarta: RinekaCipta.

Nurgroho, A., Andini, R., \& Raharjo, K. (2016). Effects of taxpayer awareness and taxpayer knowledge of taxpayers on compliance of taxpayers in paying income taxes(Case Study on KPP Semarang Candi). Journal of Accounting, 2(2), 1-13.

Nurkhin, A., Novanty, I., Muhsin, M., \& Sumiadji, S. (2018). The influence of tax understanding, tax awareness and tax amnesty toward taxpayer compliance. Journal of Finance and Banking, 22(2), 240-255.

Nurmantu, S. (2010). Introduction to Taxation Science,(Issue 3). Jakarta: Granite.

Oladipupo, A.O., \& Obazee, U. (2016). Tax knowledge, penalties and tax compliance in Small and Medium scale enterprises in Nigeria. iBusiness, 2(1), 1-9

Olaoye, C. O., Ayeni-Agbaje, A. R., \& Alaran-ajewole, A. P. (2017). Tax information, administration and knowledge on tax payers' compliance of block molding firms in Ekiti State. Journal of Finance and Accounting, 5(4), $131-138$.

Palil, M. R., Rusyidi, M. A., \& Ahmad, W. F. (2013). The perception of tax payers on tax knowledge and tax education with level of tax compliance: A study of the influences of religiosity. ASEAN Journal of Economics, Management and Accounting, $1(1), 118-129$.

Rahayu, S.K. (2010). Indonesian Taxation: Formal Concepts and Aspects. Yogyakarta: GrahaIlmu.

Rahayu, N. (2017). The influence of tax knowledge, firmness of tax sanctions and tax amnesty on taxpayer compliance. Dwantara Accounting, 1(1), 15-30.

Rahmawati, R., \& Yulianto, A. (2018). Analysis of the factors affecting individual taxpayers compliance. Accounting Analysis Journal, 7(1), 17-24.

Redae, R. B., \& Sekhon, S. (2016). Tax payers' knowledge and tax compliance behavior in Ethopia: A study of Tigray State. International Journal of Management and Commerce Innovations, 3(2), 1090-1102.

Sari, V. A., \& Fidiana (2017). The effects of tax amnesty, taxation knowledge, and fiscus services on taxpayer's discipline. Journal of Science and Accounting Research, 6(2), 744-759.

Savitri, E., \& Musfialdy. (2016). The effect of taxpayer awareness, tax socialization, tax penalties, compliance cost at taxpayer compliance with service quality as mediating variable. Procedia - Social and Behavioral Sciences, 2(19), 682-687.

Siat, C. C., \& Toly, A. A. (2013). Factors affecting taxpayer compliance in meeting tax paying obligations in Surabaya. Tax \& Accounting Review, 1(1), 41-48.

Sugiyono (2013). Business Research Methods: Quantitative, Qualitative Approaches and R\&D. Bandung: Alfabeta.

Suryadi, (2006). Causal model of awareness, service, taxpayer compliance, and its effect on tax revenue performance. Journal of Public Finance, 4(1), 105-121.

Taslim. (2007). Tax Knowledge. Jakarta: Generasis.

Widodo, J. (2001). Good Governance: Accountability and Bureaucratic Control. Surabaya: InsanCendikiawan.

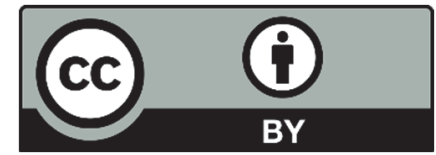

(C) 2021 by the authors; licensee Growing Science, Canada. This is an open access article distributed under the terms and conditions of the Creative Commons Attribution (CC-BY) license (http://creativecommons.org/licenses/by/4.0/). 